\title{
From Durkheim to Czarnowski: Sociological Universalism and Polish Politics in the Interwar Period
}

\author{
Joanna Wawrzyniak* \\ Institute of Sociology, University of Warsaw, ul. Karowa 18, 00-927 Warszawa \\ *wawrzyniakj@is.uw.edu.pl
}

The Durkheimian School of sociology was one of the most comprehensive programmes ever developed in the social sciences. This article contributes to those accounts of the School that discuss its intergenerational, interdisciplinary and international transformations after the Great War. From this perspective, the article presents the case of a Polish scholar, Stefan Czarnowski (1879-1937), whose early work on the cult of St. Patrick in Ireland became one of the Durkheimian classics on social integration. In the interwar period Czarnowski argued against race studies and anti-social concepts of culture and called for sociologically grounded comparative world history ordered around the notions of class and work. More generally, Czarnowski's reconfiguration of Durkheimian universal principles in the specific location of East Central Europe calls for a deeper historicisation of the Durkheimian School as a movement in international social sciences.

'My Dear Master, I am infinitely grateful for what you did for me and my humble work. . . During my rather long studies, no one has ever bestowed such a favour upon me: my German seminar papers have never been so meticulously reviewed', ${ }^{1}$ wrote a Polish student, Stefan Czarnowski (1879-1937), to his French mentor, the Durkheimian sociologist and a historian Henri Hubert (1872-1927). Czarnowski was thanking Hubert for his comments on ideas that he would later turn into his life-work, The Cult of Heroes and Its Social Conditions (1919). ${ }^{2}$ The letter, written in 1905, skilfully played out the hierarchies and animosities of the sciences of the fin de siècle. A few years earlier its author had been expelled from Berlin for taking part in Polish students' demonstrations against Theodor Schiemann, a founder of German historical research on Eastern Europe, who claimed the civilisational inferiority of this region and advocated its incorporation into the German Empire. ${ }^{3}$ Chased also by Russian police in his native land,

I would like to thank Marta Bucholc (University of Bonn), Kornelia Kończal (TU Dresden), Katherine A. Lebow (University of Oxford), Małgorzata Mazurek (Columbia University), Jan Wawrzyniak (University of Warsaw), participants of the Colloquium on Sociological Issues of Department of Sociology (University of Virginia, 6 April 2017) and the anonymous reviewers of Contemporary European History for all their insight and expertise that helped greatly to improve this article, although they may not agree with all of its interpretations. This research was generously supported by the National Programme for the Development of Humanities (NPRH) of the Minister of Science and Higher Education in Poland, in 2015-18. Grant no 0133/NPRH4/H1b/83/2015.

1 Czarnowski, 'À Henri Hubert, Paris, 1er octobre 1905', in Stefan Czarnowski, Listy do Henri Huberta i Marcela Maussa (1905-1937)/Lettres à Henri Hubert et à Marcel Mauss (1905-1937), eds., Kornelia Kończal and Joanna Wawrzyniak, trans. Filip Rogalski and Damien Thiriet (Warszawa: Oficyna Naukowa, 2015), 221. Czarnowski had actually studied in Leipzig and Berlin with some of the greatest German scholars of the time, including Karl Bücher, Karl Lamprecht, Georg Simmel and Wilhelm Wundt. See, Czarnowski, Listy, 186.

2 Stefan Czarnowski, Le Culte des héros et ses conditions sociales. Saint Patrick, héros national de l'Irlande, préface d'Henri Hubert (Paris: Alcan, 1919).

3 Ryszard Ergetowski, 'Schiemann-Skandal. Karta z dziejów studenckiej Polonii w Berlinie (1901)', Rozprawy z Dziejów Oświaty, 24 (1981), 111-41.

() Cambridge University Press 2018. 
Czarnowski found a safe haven in Paris, where he spent nearly ten years (1902-11) and became captivated by the emerging Durkheimian School in sociology. The intellectual fascination was fuelled by anti-German resentments shared by the Polish intelligentsia, who aspired to independence, and by the French after their defeat in the Franco-Prussian War.

However, much more was at stake for the Durkheimian School than these international rivalries. As historians of sociology repeatedly note, the discipline arose in the late nineteenth century from an effort to understand the processes of modernisation and from hopes to gain control over their consequences. ${ }^{4}$ The Durkheimian School in particular played a key role in the rise of the social sciences because of its universalising ambitions. Durkheimians aimed to offer a theory and method to study all world societies: historical and contemporary, traditional and modern, European and colonial. They also actively took part in political discussions, seeking the basis of social integration in times of rapid social change. ${ }^{5}$ The so-called French school in sociology owned its global career, however, most of all to a cohort of effective cultural brokers. The French scholar Laurent Mucchielli once wrote of the need to 'kill the father' in order truly to understand the career of a school of thought. To that end, Mucchielli proposed to concentrate instead on his collaborators, students and adversaries. ${ }^{6}$ This article goes further by showing that, in order to understand the development and transformation of a paradigm, one also needs to look beyond its country of origin.

The passionate Durkheimian, Stefan Czarnowski, is a case in point. Active for ten years in France before the Great War, he became one of the founders of Polish sociology when his country regained independence in 1918. His two books, The Cult of Heroes and Its Social Conditions: Saint Patrick, the National Hero of Ireland (hereafter The Cult) and Culture (1938) ${ }^{7}$ became canonical readings in Polish humanities. Not only did Czarnowski leave a legacy of Durkheimian influence in Polish sociology, he also inspired a generation of Polish historians to use a comparative method. Some of his essays, such as his 'Redundant People in the Service of Violence' on the threat of fascism, ${ }^{8}$ later became standard references for Poland's leftist intellectuals. ${ }^{9}$ In the 1930s, moreover, another émigré living in Paris, James Joyce, was inspired by Czarnowski's work to write his last novel, Finnegans Wake (1939). ${ }^{10}$ Both Czarnowski's interests in Ireland and Joyce's attention to Czarnowski's The Cult show that the transfer of ideas was not necessarily only from West to East, but had its peculiar byways among European peripheries. Internationally, however, Czarnowski is still largely unknown outside the communities of religion scholars or specialists on the Durkheimian School. His first book is available only in French (with a Polish translation), and most of his later writings are in Polish only. ${ }^{11}$

\footnotetext{
4 See, for example, Peter L. Berger, 'Sociology: A Disinvitation?', Society, 30, 1 (1992), 12-8; Lewis A. Coser, Masters of Sociological Thought: Ideas in Historical and Social Context (New York: Harcourt Brace Jovanovich, 1977); Jerzy Szacki, Historia myśli socjologicznej (Warszawa: PWN, 2017); Piotr Sztompka, The Sociology of Social Change (Oxford: Blackwell, 1993).

5 For recent comprehensive accounts in English, see Marcel Fournier, Émile Durkheim: A Biography, trans. David Macey (Cambridge: Polity Press, 2013); Johan Heilbron, French Sociology (Ithaca, NY: Cornell University Press, 2015), 59-123.

6 Laurent Mucchielli, La Découverte du social. Naissance de la sociologie en France, 1870-1914 (Paris: La Découverte, 1998).

7 Stefan Czarnowski, Kultura (Warszawa: Biblioteka Wiedzy i Życia, 1938).

8 Stefan Czarnowski, 'Ludzie zbędni w służbie przemocy', Głos Współczesny, 1, 1 (1935), 1-8. English translation: Stefan Czarnowski, 'Redundant People in the Service of Violence', trans. Tristan Konecki and Aaron Law, Acta Poloniae Historica, 114 (2016).

9 Most recently, Zygmunt Bauman, Wasted Lives: Modernity and Its Outcasts (Cambridge: Polity Press, 2004).

10 James Joyce, Finnegans Wake (London: Faber and Faber, 1939); Riana O’Dwyer, 'Czarnowski and Finnegans Wake: a study of the cult of the hero', James Joyce Quarterly, 17, 3 (1980).

11 For a complete edition of Stefan Czarnowski's works, see Stefan Czarnowski, Dzieła, 5 vols., ed. Nina Assorodobraj and Stefan Ossowski (Warszawa: PWN, 1956). There has been no full-fledged intellectual biography of Stefan Czarnowski as yet. For the most recent discussion of Czarnowski's life and work in the French-Polish context with the most up-to-date bibliography see Czarnowski, Listy, 173-217, 358-405. For the other most comprehensive treatments so far, see Nina Assorodobraj, 'Życie i dzieło Stefana Czarnowskiego' in Czarnowski, Dzieła, Vol. 5, 105-56; Marek Jabłonowski, ed.,
} 
Analysing Stefan Czarnowski's writings in both languages as well as the reception of his work, this article argues that the classical sociology which develoed between the 1890s and 1930s succeeded in dealing with the big questions of the time - modernisation, nationbuilding, social conflicts - not only thanks to its early masters. ${ }^{12}$ Rather, it owed its global success to those of their students who were cultural brokers - mediators, like Czarnowski, between disparate linguistic and cultural constellations of scholarship. ${ }^{13}$ This 'brokering' process needs to be studied in all its complexity to reveal an accurate picture of the discipline's development. From a general historical point of view, such sociological conversions are important because they indicate how key concepts organising modern imagination, for example, society, nation and class, kept changing across time and space. This article therefore uses the case of Czarnowski's involvement with the Durkheimian School to focus on three intertwined issues, hoping to contribute to a nuanced rethinking of the transnational history of sociology. 14

First, it highlights the East Central European (ECE) aspects of the transnational circulation of knowledge in the period of classical sociology. According to older narratives, after the Great War the Durkheimian School decayed. It failed to attract new disciples and institutional support because of the deaths of Émile Durkheim (1858-1917) and many of his students. ${ }^{15}$ In more recent accounts, however, several authors have stressed the metamorphoses of Durkheimianism, its survival in more and more specialised fields of the social sciences and its impact on disciplines other than sociology. ${ }^{16}$ Randall Collins claims that the Durkheimian School's legacy was actually saved outside of France, not because of its direct transfer but rather owing to the 'meshing' of scholarly networks and ideas. For instance, this was the case with British social anthropologists who began to adopt the Durkheimian programme as part of their own research agenda, or with the sociological projects of Talcott Parsons, W. Lloyd Warner and Erving Goffman in the United States. ${ }^{17}$

In such general outlines of Durkheimianism's interwar transformations, East Central Europe has been absent, even though for many scholars from the region, Paris was formative to their education, complementing or competing with Vienna, Leipzig, Berlin and St. Petersburg. Since Durkheim's opening lecture at the Sorbonne in 1902, his and his collaborators' teaching was followed, disputed or challenged by members of a generation that contributed to the institutionalisation of social sciences in ECE: Edvard Beneš (1884-1948), Antonín Uhlír (1882-1957)

Stefan Czarnowski z perspektywy siedemdziesięciolecia (Warszawa: Aspra-JR); Janina Markiewicz-Lagneau, La Formation d'une pensée sociologique. La société polonaise de l'entre-deux-guerres (Paris: Éditions de la Maison des sciences de l'homme, 1982), 187-200.

12 Cited from Berger, 'Disinvitation', 12.

13 The body of literature on cultural brokers in science is growing, however not so much in history of sociology. For a discussion of this and related concepts see Kapil Raj, 'Go-Betweens, Travelers, and Cultural Translators', in Bernard Lightman, ed., A Companion to the History of Science (Hoboken, NJ: Wiley-Blackwell, 2016), 39-58.

14 On transnationalisation in sociology, see Gurminder K. Bhambra, Connected Sociologies (London: Bloomsbury Academic, 2014); Christian Ersche, Ercüment Çelik, Veronika Wöhrer and Wiebke Keim, eds., Global Knowledge Production in the Social Sciences: Made in Circulation (London: Ashgate, 2014); Johan Heilbron, Nicolas Guilhot and Laurent Jeanpierre, 'Toward a Transnational History of the Social Sciences', Journal of the History of the Behavioral Sciences, 44, 2 (2008), 146-60.

15 Terry N. Clark, Prophets and Patrons. The French University and the Emergence of the Social Sciences (Cambridge, MA: Harvard University Press, 1973), 242. Victor Karady, 'The Durkheimians in Academe. A Reconsideration', in Philippe Besnard, ed., The Sociological Domain: The Durkheimians and the Founding of French Sociology (Cambridge: Cambridge University Press, 1983), 88.

16 Johan Heilbron, 'Les métamorphoses du durkheimisme, 1920-1940', Revue française de sociologie, 26, 2 (1985), $203-37$. See also Heilbron, French Sociology, 92-123; Jean-Christophe Marcel, Le durkheimisme dans l'entre-deux-guerres (Paris: Presses Universitaires de France, 2001); François Dosse, L'Histoire en miettes. Des 'Annales' à la 'nouvelle histoire' (Paris: La Découverte, 1987); Isabelle Gouarné, 'Marxisme et Durkheimisme dans l'entre-deux-guerres en France', Durkheimian Studies, 17 (2011), 57-79.

17 Randall Collins, 'The Durkheimian movement in France and in world sociology', in Jeffrey C. Alexander and Philip Smith, eds., The Cambridge Companion to Durkheim (Cambridge: Cambridge University Press, 2005), 101-35. 
and Inocenc A. Bláha (1879-1960) in Czechoslovakia, ${ }^{18}$ Jan Bystroń (1892-1964) and Florian Znaniecki (1882-1958) in Poland, Dimitrie Gusti in Romania (1880-1955), ${ }^{19}$ Oszkár Jászi (1875-1957) in Hungary ${ }^{20}$ and many others. The academic mobility of East Central European scholars at the twilight of European empires allowed for the institutionalisation of sociology in the new nations states of the interwar period. However, general social scientific paradigms were reformulated in the local frames of ECE; the case of Czarnowski indicates that the movement of ideas was anything but straightforward reception.

Secondly, by exploring the intersection of Czarnowski's life and work, this article argues for the specifically Polish subtext in his use of key tenets of Durkheimian sociology. In this respect, Czarnowski's political papers are a revealing object of study, supplementing his scholarly publications. As a young man he was a Polish nationalist who looked for the foundations of social integration in religious and national representations. At the end of his life, disappointed by the nation state, he turned to the radical left and concepts of work and class. These concepts also became central to a theory of culture in which Czarnowski articulated a sociologically-oriented vision of comparative world history, and to a critique of European capitalism with its colonial expansion.

Thirdly, this article argues that in order to understand the transnational history of sociology, one must attend to the now largely forgotten intellectual trends of the time. Czarnowski was one of the first sociologists to make a claim on the social functions of the past. He derived this from his studies of Celtic legends, rituals and calendars. ${ }^{21}$ Moreover, his projects were developed against the backdrop of the Durkheimians' polemics with other schools of thought, including race theories, historical idiography or cultural diffusionism. For political and emotional reasons he did not trust German scholarship. This article therefore reveals the intellectual context in which certain long-lived ideas were conceived.

The article is organised as follows: the first part introduces Czarnowski as a Polish public intellectual in search of a political identity. The next section recapitulates some aspects of the Durkheimian School to shed light on Czarnowski's first book The Cult; it also indicates the significance of the book, from James Joyce's reception to its reading by Polish intellectuals. Then, the article reveals how interwar developments influenced Czarnowski's analytical categories, leading him, in his work Culture, to abandon 'nation' for the sake of 'class' and 'work', and, finally, it briefly discusses some aspects of his intellectual legacy. On the whole, the article shows

18 Miroslav Petrusek, 'Émile Durkheim v české sociologii', in Zuzana Kusá and Miroslav Tížik, eds., Elementárne formy sociologického myslenia. Současné reflexe Durkheimovho diela (Bratislava: Sociologicky ústav SAV, 2009), 35-55.

19 See Raluca Musat's contribution on this issue; Gabriela F. Georgevici, Monographic Sociology of Dimitrie Gustie: Social Science and Reform (Frankfurt am Main: Peter Lang, 2013).

20 György Litván, A Twentieth-Century Prophet: Oscar Jászi 1875-1957 (Budapest: Central European University Press, 2006); Balázs Trencsényi, Maciej Janowski, Monika Baár, Maria Falina and Michal Kopeček, A History of Modern Political Thought in East Central Europe, Vol. I: Negotiating Modernity in the 'Long Nineteenth Century' (Oxford: Oxford University Press, 2015), 437-.

21 Only limited attention has been paid to the use of Celtic history in the making of modernity despite significant research on how ancient utopias became an important part of the projection of identity in the nineteenth century and on how the Greeks and Romans were reinvented to serve political programmes of the Western European bourgeoisie and Eastern European intelligentsia. See, François Hartog, Anciens, modernes, sauvages (Paris: Galaade, 2005); Gábor Klaniczay, Michael Werner and Ottó Gecser, eds., Multiple Antiquities - Multiple Modernities: Ancient Histories in Nineteenth Century European Cultures (Frankfurt am Main: Campus Verlag, 2011); Alexandra Lianeri, ed., The Western Time of Ancient History (Cambridge: Cambridge University Press, 2011). On Celts, see Sabine Rieckhoff, 'Celtes et Gaulois dans l'Histoire, l'historiographie et l'idéologie moderne', in Christian Goudineau, Vincent Guichard and Gilbert Kaenel, eds., Celtes et Gaulois L'archéologie face à l'histoire. Colloque de synthèse (Glux-en-Glenne: Collection Bibracte, 2010), 17-35; Sabine Rieckhoff, 'Les Celtes: people oublié ou fiction?' in L'archeologie, instrument du politique? Archéologie, histoire des mentalités et construction européenne (Bourgogne : CRDP, 2006), 25-42; Malcolm Chapman, The Celts: The Construction of a Myth (Basingstoke: The Macmillan Press, 1992). See also the recent research on Henri Hubert, discussed below. 
how the French School was transformed in the Polish locality to answer global concerns of the time.

\section{Stefan Czarnowski: In Search of Political Identity}

Like many other busy men of his generation and place of origin, in the course of his life Stefan Czarnowski performed multiple social roles, including those of a scholar, soldier, political émigré and a public intellectual in his native realm. However, the evolution of his political views from the right to the left was quite exceptional. Born into a family of wealthy gentry in Kroczewo, not far from Warsaw (at the time within the Russian Empire), as a young man he was a proponent of Polish radical nationalism. He was an active member of the Association of the Polish Youth 'ZET', the youth organisation of National Democracy (Narodowa Demokracja, or Endecja), a political movement supported by Catholic Polish intelligentsia, urban lower middle class dwellers and by some bourgeoisie and landowners. ${ }^{22}$ Many of Endecja's early activities supported Polish aspiration to independence and opposed the Prussian policies of Germanisation and cultural war (Kulturkampf) against the Catholic Church. (Czarnowski's own engagement in these activities resulted in his expulsion from Berlin.)

However, driven by its leader's - Roman Dmowski's - social-Darwinist ideas, Endecja turned soon also against other nationalities within the former Polish lands, most notably against the Jews, whose forced migration from the Ukraine and inner Russia was perceived as a threat to the economic survival of Poles in the overpopulated territories under Russian and Austrian rule. ${ }^{23}$ Such were Czarnowski's views even after he returned from Paris where he had spent ten years in a milieu of devout Dreyfusards. ${ }^{24}$ The French Durkheimians were at the liberal left of the intellectual life of the Third Republic, and Czarnowski was on the right of the Polish political spectrum, for which his anti-Semitism is a telling indicator. Although he had left the ranks of the National Democrats and joined a 'Secession' (Secesja) group in a token objection to Roman Dmowski's pro-Russian policy, he expounded a whole universe of integral nationalism in the 'Polish Weekly' (Tygodnik Polski), the journal he co-founded and ran in Warsaw, in which he warned his readers against a 'Jewish attack' on Poland and recommended that

we should at long last recognise that he who sells his land to a jew [sic] is equally demoralised and equally injurious to our nation as those who sell their patrimonies to the [Prussian] Settlement Commission or to others, foreign to us. Let them go join the jews, all these whom jewish monies appear sweeter than a fundamental national duty. The Poles must have nothing to do with them. ${ }^{25}$

During the Great War Czarnowski expressed his patriotism as a recruitment officer in the Austria-affiliated wing of the Polish Legions and, later, as the commander of an infantry unit in heavy combat operations in Ukraine during the Polish-Soviet War (1919-21). The rural country that finally appeared on the map of Europe out of the turmoil of these two wars certainly was not an Endecja dream. In 1921, out of approximately 27 million of its inhabitants only 62.5 per cent were Roman Catholics. Almost a third of population came from minority groups: Ukrainians, Jews (making for the second largest Jewish population in the world), Belarusians, Germans, Czechs, Lithuanians and Russians. The social structure was uneven and polarised with most of

\footnotetext{
22 See, for example, Brian Porter, When Nationalism Began to Hate: Imagining Modern Politics in Nineteenth-Century Poland (New York, Oxford: Oxford University Press, 2000), 189-.

${ }^{23}$ Grzegorz Krzywiec, Chauvinism, Polish Style: The Case of Roman Dmowski, trans. Jarek Garliński (Frankfurt am Main: Peter Lang Edition, 2016).

24 Anti-Semitism for them was a symptom of 'social malaise' (anomie) caused by modernity. See, for example, Chad A. Goldberg, 'Introduction to Emile Durkheim's “Anti-Semitism and Social Crisis”', Sociological Theory, 26, 4 (2008), $299-323$.

25 Stefan Czarnowski, 'Atak Żydowski', Tygodnik Polski, 17 (1914), 257-60.
} 
the economic wealth in the hands of only 1.4 per cent of the people (landowners and bourgeoisie). The rest were peasants (55), workers (27.5), petit bourgeoisie and intelligentsia (16).

Already in the 1920s Czarnowski became disillusioned with the political situation of the time. In his personal letters to Hubert he complained of a crisis in public institutions, of state violence, inflation, economic chaos and the impoverishment of society. Soon he declared himself a resolute opponent of National Democracy, which he saw as politically responsible for the climate of antiSemitic hatred in which a nationalistically minded painter and art critic, Eligiusz Niewiadomski, had assassinated the first President of Poland, Gabriel Narutowicz (1922). ${ }^{26}$ At this time, the first compassionate feelings towards the working class can be found in Czarnowski's writings, as he described with outrage the shootings of protesting workers during anti-government riots in Kraków in $1923 .^{27}$

And yet he did not support the most prominent opponent of National Democracy, Marshal Józef Piłsudski, nor did he tolerate Piłsudski’s coup of May 1926 and the subsequent authoritarian Sanation (Sanacja) regime. Piłsudski, the key person in Polish politics and military since the Great War, and formerly the Chief of State (1918-22), saw the constant power shifts in the Polish parliamentary democracy as internally and internationally damaging. When the regime, backed by military officers and the cult of personality surrounding Piłsudski, aspired to a moral healing of Polish politics, Czarnowski wrote in September 1928 to Marcel Mauss, 'Mussolini and Primo de Rivera would have been enough for me. The atmosphere in Poland is rather stifling'. ${ }^{28}$

In 1929 Czarnowski joined the Polish Socialist Party (Polska Partia Socjalistyczna; PPS), the main antagonist of Endecja since the late nineteenth century. Despite never having been close to this organisation, he did so as a gesture of support for the parliamentary opposition as their confrontation with the government camp grew increasingly strained. Czarnowski became radicalised, however, after the arrests and trials of many centre-left politicians in 1930-2, the pacifications of the Ukrainian minority (1930) and, above all, after the consequences of the Great Depression were made apparent - the growth of unemployment (up to over forty percent) and considerable food shortages all over the country. Under these circumstances Czarnowski quit the PPS in 1931, explaining his reasons in an open letter published in a leaflet The Socialist Worker (Robotnik Socjalistyczny) in February 1932. There, he criticised the reformism of the PPS, arguing that its adherence to liberal bourgeois democracy played into the hands of the ruling elite, who sought 'a system in which the working masses would be completely dependent upon the possessing classes: namely, fascism'. ${ }^{29}$

Hence, the communist movement was for Czarnowski a feasible option against fascism. He kept in touch with members of the Communist Party of Poland (Komunistyczna Partia Polski; $\mathrm{KPP}$ ), although the nature of his connection remains unclear. After Hitler's coming to power in Germany he pledged support for a popular front to resist the radical right, a policy proposed by the Seventh Congress of the Communist International. ${ }^{30}$ At Warsaw University he acted as a mentor to a group of socialist students, supervising their research on the work and everyday life of urban youth. Outside the university he lectured to printers and workers, and he established contacts with left-wing teachers sympathising with the Popular Front as a co-founder of the Society for Democratic Education New Tracks (Nowe Tory) and a magazine Contemporary Voice (Głos Współczesny). It was in this periodical that his landmark essay, 'Redundant People in the

\footnotetext{
${ }^{26}$ Narutowicz was supported by the National Minorities' Bloc (including Jews) in the National Assembly. The anti-Semitic riots are described by Paul Brykczynski, Primed for Violence: Murder, Antisemitism, and Democratic Politics in Interwar Poland (Madison: University of Wisconsin Press, 2016).

27 Czarnowski, Listy, 108.

28 Czarnowski, Listy, 330.

29 Quoted from Joanna Wawrzyniak, 'Archive' [Introduction to Czarnowski, 'Redundant People'], trans. Tristan Korecki and Aaron Law, Acta Poloniae Historica, 114 (2016), 293.

30 On Czarnowski's communist involvement see Tomasz Nałęcz, 'Jeden z pokolenia niepokornych', in Jabłonowski, Stefan Czarnowski, 60-.
} 
Service of Violence', was published, in which he blamed the state for inadequate reform of the education and insurance systems and claimed that poor and unemployed youth, seduced by the far right, were the main threat to public and social order. ${ }^{31}$

Together with his political affiliation, Czarnowski's attitude to Jews changed dramatically. He was among a small number of professors who publicly condemned the anti-Semitic policies introduced at Polish universities and opposed them in practice. ${ }^{32}$ One of his former students recalled:

Czarnowski's seminar on ancient Celtic culture resembled a lecture to a small group seated around a table. In it, he clearly presented a system of links and interpretations encompassing myths, economy, crafts, emblems, rites, feasts and artefacts. . . But that was not the only reason why I was attracted to Czarnowski. His 'Positive Sociology' students' research group was one of only two at the University of Warsaw that still accepted Jews as members. ${ }^{33}$

Such radical changes in worldview were exceptional, but at the same time, Czarnowski's multiple political personalities reflected some of the acute dilemmas faced by the Polish intelligentsia in the first half of the twentieth century. Their dream of a nation state providing for the harmonious development of society once its enemies were gone had not come true. Economically, the country was worse off than before the outbreak of the war. The violence did not cease. State politics appeared to be a sphere of exploitation - not emancipation; not the minorities hampered social integration, but those obliged to provide for it. In effect, Czarnowski converted to another dream, a communist project, supposed to liberate not only Poles, but all the exploited people. With his sudden death in 1937 he did not live long enough to check and balance these ideas.

\section{Celts, Saints and Nations}

Despite profound changes in his political ideas, Czarnowski was consistent in his sociological identity. His Durkheimian background turned out to be flexible enough to embrace both his nationalistic and communist predilections. In what follows, therefore, this article indicates how Czarnowski's Durkheimian education helped him intellectually to process the concerns of his time. Czarnowski arrived in Paris in 1902, the same year that Émile Durkheim, having previously published his major works on The Division of Labour in Society (1893), Suicide (1897) and The Rules of Sociological Method (1895), and having launched the sociological journal L'Année Sociologique (1898), moved from Bordeaux to Paris, obtained the chair of education at the Sorbonne and commenced lecturing to wide groups of students. The circle of his enthusiasts was growing into a movement of scholars of various backgrounds and specialisations who helped develop the most ambitious undertaking ever conceived in social science. Men like Celestin Bouglé, Paul Fauconnet, Maurice Halbwachs, Robert Hertz, Henri Hubert, Marcel Mauss, Gaston Richard, François Simiand and many others viewed the new sociological project as encompassing a vast array of disciplines: economics, law, political sciences, psychology, philology, religious studies, ethnology, history and archaeology. At the same time, sociology was to be separated from philosophy, liberated from theology, ready to look for law-like regularities, but also differentiated from natural sciences because its object - human societies - constituted a distinctive realm to be captured empirically in specific categories of social facts. ${ }^{34}$

Within a few years Czarnowski became attached to Durkheim's closest collaborators: his nephew Marcel Mauss, one of the founders of French anthropology, and Henri Hubert, an

\footnotetext{
31 Czarnowski, 'Redundant People'.

32 See, for example, Stefan Czarnowski, 'Zajścia antysemickie w szkołach wyższych', Głos Współczesny, 2, 2 (1935), 19-24.

33 Jan Kott, Przyczynek do biografii (London: Aneks, 1990), 62.

34 Johan Heilbron, French Sociology (Ithaca, NY: Cornell University Press, 2015), 74-6.
} 
archaeologist and specialist in Celtic history. ${ }^{35}$ For several years Czarnowski attended their seminars at L'École pratique des hautes études (EPHE). It is within the framework of Hubert's Primitive Religions of Europe, with its focus on feasts, calendars and representations of gods and heroes, that Czarnowski completed his dissertation on the cult of St Patrick in Ireland at EPHE in 1911. This was published after the war as the sixth volume of the series Travaux de L'Année sociologique, launched by Émile Durkheim. ${ }^{36}$

The significance of The Cult can be understood in relation to some of the Durkheimians' key preoccupations. Their central question was that of the mechanisms of social cohesion in the time of modernisation, when traditional, repetitive 'mechanical' bonds were no longer in operation, and when new social institutions were to be developed to assure the 'organic' integrity of societies. However, the method and the seeming paradox of the School was that it tried to explore modernity by studying religious representations in pre-modern societies. In particular, its core circle - including Durkheim, Hubert and Mauss - believed that they ought to look at indigenous and ancient societies because, thanks to their 'lesser complexity', insights could be gained into the very essence of society, its common, principal and universal features. One of the most important concepts they popularised was 'collective representations', standing for beliefs, values and symbols shared by community members and connected to their affects and emotions. Often conveyed in rituals, collective representations were an expression of social relations and a tool for their regulation. Durkheimians also thought that representations from the sacred sphere (such as the totem) stood for the most important values; societies worshipped the sacred because they represented themselves in it.

Moreover, convinced that sociology should not stop at mere descriptions, the Durkheimians used comparative methods to seek out universal societal mechanisms. Their understanding of comparison was broad, allowing for diachronism and synchronism within and across societies. But even with individual case studies (like Durkheim's Elementary Forms or Czarnowski's Cult), they attempted to relate their own research outcomes to a whole range of other cases. Hence, their research programme required empirical evidence drawn from laborious studies of sources in many languages and knowledge of many disciplines over which their claimed sociology's superiority.

Such sociological imperialism engaged the Durkheimians in energetic polemics with the proponents of historical idiographic methods, psychological introvertism, geographical determinism and racial science. ${ }^{37}$ They turned for source material to history, but they disparaged its lack of generalisations. In contrast to psychology and psychoanalysis, they claimed that emotions are collectively constructed and that an individual can only meaningfully recall the past within the social frameworks of language, space and time. In geography they rejected the supposed biological determinants of geopolitics that justified imperial expansion. Finally, as the Durkheimians asserted the primacy of the social over any other determinants of human organisation, they were among the most forceful opponents of race theories circulating within and

\footnotetext{
35 Whereas Mauss became a household name in the social sciences worldwide, his best friend and co-author of most important publications, Henri Hubert, is being rediscovered only now by both sociologists and archaeologists. See, for example, Jean-François Bert, Marcel Mauss, Henri Hubert et la sociologie des religions. Penser et écrire à deux (Paris: La Cause des Livres, 2012); Bert, ed., Henri Hubert et la sociologie des religions. Sacré, Temps, Héros, Magie (Liège: Presses Universitaires de Liège, 2015); Christine Lorre, 'Henri Hubert et les perspectives sociologiques mises en oeuvre au Musée des Antiquités nationales', in Christine Laurière, ed., 1913. La recomposition de la science de l'Homme, Les Carnets de Bérose, 7 (2015), 144-55, available at http://www.berose.fr/IMG/pdf/1913_30_04.pdf (last visited 27 Jan. 2017); Laurent Olivier, ed., La mémoire et le temps. L'auvre transdisciplinaire d'Henri Hubert (1872-1927) (Paris: Editions Demopolis, 2017).

36 Czarnowski, Le Culte. The prints were ready before the war. Philippe Besnard, ed., 'Lettres de Émile Durkheim à Henri Hubert', Revue française de sociologie, 28, 3 (1987), 532.

37 Steven Lukes, Emile Durkheim: His Life and Work. A Historical and Critical Study (Stanford: Stanford University Press, 1985); Mucchielli, La Découverte du social.
} 
beyond the academia of that time. This might be surprising in the light of Czarnowski's early anti-Semitic writings. To be sure, his Polish political papers were never meant to be read by his French mentors and were at odds with the liberal Durkheimian outlook; but his anti-Semitism was economic and cultural, not racist. This did not make his views any less damaging at the time, but it mattered for Czarnowski's intellectual consistency. As shown later, he always advocated social - not racist - grounds for studying societies along the general line of the Durkheimians.

Finally, for Czarnowski like for Hubert, an interest in the Celtic history and culture was a means of sharpening their sociological and political focus. A preoccupation with the Celts was hardly peculiar at the time; throughout the nineteenth century the Celts had been indicated as a lieu de mémoire by various factions, featuring in French, German and British scholarship concerned with origins, belonging and continuity. ${ }^{38}$ The Celts had alternately been linked to the social ideas of the Enlightenment, romantic nationalism, patriotism, Darwinism and pan-Celtic alternatives to a multinational Europe. By the turn of the century Celtomania had played an important role in transforming archaeology into a 'national science' and an instrument of political claim making, especially in France. ${ }^{39}$ Methodologically and ideologically, therefore, Hubert was engaged in a fight against the influence of racist anthropological theories on archaeology. 'Anthropology has nothing to say, and despite its efforts has never said anything about the Celts', wrote Hubert, stressing that 'the Celts are not a race, but a group of people, and more specifically, a social group. ${ }^{40}$ It was not ethnicity, skull dimensions or blood that identified peoples and communities but customs and social ties. ${ }^{41}$ (The historian Ivan Strenski argues that Hubert, as a representative of republican patriotism, used the 'Celtic mirror' to reflect a modern France of his own progressive dreams in opposition not only to French race theorists, but also, and more pertinently, to German and British conceptions of Aryan and Germanic superiority. ${ }^{42}$ ) Himself a specialist in continental Celtic history, it was Hubert who encouraged Czarnowski to study the history of Ireland.

This is how Czarnowski came to explore the Latin hagiographies of St. Patrick, the legendary agent of Ireland's Christianisation in the early Middle Ages. Czarnowski's work considered how the cult of St. Patrick legitimised the new religion that had been imposed on the Celtic clans and unified them into a single Irish society. In the process St. Patrick was transformed into the national hero of Ireland, his image changing over time in response to changing values and political concerns. In particular, Czarnowski argued, representations of Patrick's life and death were collectively embraced as interwoven with old pagan rites and feasts; his cult also helped to overcome the conflict between two religious corporations: 'conservative' druids and 'modern' filids. To undermine the druids' position, the filids struck an alliance with Christianity, promoting the worship of saints that incorporated the traits of pagan Irish heroes. St. Patrick was the most prominent among them because the filids worshiped him as their special protector, while the Church saw in St. Patrick's cult the expression of its unity. The Irish clergy had gathered around his cult when they fought against the Roman clergy for administrative and liturgical autonomy; the Scandinavian invasions also contributed to St. Patrick's elevation as a symbol of Irish unity. ${ }^{43}$ In this way the saint was transformed into a national hero and the Irish became the forerunners of European nation building: 'Ireland had outrun the rest of Europe for several centuries', Czarnowski concluded. ${ }^{44}$

\footnotetext{
38 Rieckhoff, 'Celtes et Gaulois'; Rieckhoff 'Les Celtes'.

39 Rieckhoff, 'Celtes et Gaulois', 17-35.

40 Quoted from French edn, Henri Hubert, Les Celtes et l'expansion celtique jusqu'à l'époque de la Tène, updated edn by Marcel Mauss, Raymond Lantier and Jean Marx (Paris: La Renaissance du livre, 1932), 39, 40. English edition: Henri Hubert, The History of the Celtic People (London: Kegan Paul, 1934).

41 Hubert, Les Celtes, 223.

42 Ivan Strenski, 'Henri Hubert: Racial Science and Political Myth', Journal of the History of the Behavioral Sciences, 23 (1987), 353-67, 364.

43 For an extensive summary in English of this and other works of Czarnowski on heroes, see Ewa Sadowska, 'Stefan Czarnowski. A Forerunner of Celtic Studies', Hemispheres. Studies on Cultures and Societies, 3 (1987), 171-94.

${ }^{44}$ Czarnowski, Le Culte, 326.
} 
The work can be classified both as a historical study bound by its temporal and spatial framework (it was commented on as such by historians), ${ }^{45}$ and as a sociological generalisation beyond the empirical evidence at hand, which obviously was Czarnowski's ambition. In accordance with the Durkheimian understanding of the role of collective representations, he presented a theory of 'heroes' as emblems of societies; in this he was close to Durkheim's view of the social function of 'totems' in native Australian societies. ${ }^{46}$ For Czarnowski a defining criterion of the hero(ine) was their embodiment of the key values of a given community. He maintained, in other words, that societies represent themselves in images of heroes they praise.

Czarnowski thus made a Durkheimian intervention into the tradition of hero studies, then associated most prominently with the Scottish philosopher Thomas Carlyle, whose works were a moral guide for 'great men' aspiring to the role of political leaders. In continental philosophy, meanwhile, Friedrich Nietzsche had developed the notion of superman, and Freud's student Otto Rank had articulated a psychoanalytic interpretation of the myths surrounding heroes' births. ${ }^{47}$ Czarnowski's pioneering study was at odds with these ideas by claiming that heroes were nothing more than a projection serving the aims, hopes and aspirations of a social group. 'The notion of hero is a function of several synthetic judgements, on the one hand on how a group comprehends its existence as a community and, on the other hand, on how it emotionally relates to what constitutes its fundamental social value', he argued. ${ }^{48}$

In his lengthy introduction to Czarnowski's book, Hubert took almost a hundred pages to stress this point: he explained that even though the work was a case study, it was legitimately universal and sociological, as Czarnowski was in fact interested in the broader and fundamental question of the social functions of heroes. He pointed to the explicit and implicit wide-ranging comparisons in Czarnowski's study to show its overall value, paying attention to, inter alia, the typology of saints and heroes, with numerous examples from antiquity, Christianity and contemporary times, in places also correcting or extending Czarnowski's reasoning. ${ }^{49}$ Hubert - who himself significantly contributed to Durkheimianism with his reflections on the social construction of time - was particularly satisfied with Czarnowski's findings that heroes who were repeatedly commemorated in time unified a community more successfully than those related to a place. $^{50}$

Czarnowski's ideas circulated later on in various contexts from religious ${ }^{51}$ to hero studies. ${ }^{52}$ Their significance has been also rediscovered within the present interest in collective memory.

45 Sadowska, 'Stefan Czarnowski', 175; Joseph Vendryès, [review] 'Stefan Czarnowski. Le Culte des héros...', Revue celtique, 38 (1920-1), 332-8.

46 Isambert, 'At the frontier', 172.

${ }^{47}$ For some discussion see: Linas Eriksonas, National Heroes and National Identities: Scotland, Norway and Lithuania (Brussels: P.I.E - Peter Lang, 2004), 31-.

48 Czarmowski, Le Culte, 234.

49 Not knowing Czarnowski's situation during the Great War, Hubert published his long preface in Revue de l'histoire des religions, 70, 71 (1914-5) before the actual book came out. For the English translation, see Henri Hubert, 'Preface to Saint Patrick and the Cult of the Hero', in Marcel Mauss, Henri Hubert and Robert Hertz, Saints, Heroes, Myths, and Rites: Classical Durkheimian Studies of Religion and Society, ed. and trans. Alexander Riley, Sarah Daynes and Cyril Isnart (Boulder-London: Paradigm Publishers, 2009), 39-87.

50 Isambert, 'At the frontier', 165.

51 See, for example, Jacques Maître, 'La sociologie du catholicisme chez Czarnowski, Halbwachs, Hertz et Van Gennep', Archives de sociologie des religions, 11, 21 (1966), 55-68; François-André Isambert, 'At the frontier of folklore and sociology. Hubert, Hertz and Czarnowski, founders of a sociology of folk religion', in Philippe Besnard and Lewis A. Coser, eds., The Sociological Domain: The Durkheimians and the Founding of French Sociology (Cambridge: Cambridge University Press, 1983), 152-76; Alina Osiadacz-Molska, 'Stefan Czarnowski i jego dzieła (Przegląd problematyki religioznawczej w pismach Stefana Czarnowskiego)', Eihemer, 5 (1958), 48-60.

52 See, for example, Pierre Centlivres, Daniel Fabre and Françoise Zonabend, eds., La Fabrique des héros (Paris: Éditions de la Maison des sciences de l'homme, 1999); Alain Chenu, 'From Paths of Glory to Celebrity Boulevards: Sociology of Paris Match', Revue française de sociologie, 5, 51 (2010), 69-116; Maria Todorova, Bones of Contention: The Living Archive of Vasil Levski and the Making of Bulgaria's National Hero (Budapest: Central European University Press, 2009), 478, 482. 
For instance, the sociologist Barry Schwartz rightly observed that Czarnowski's book enlarged 'Durkheim's understanding of the social framework of commemoration' and complemented Maurice Halbwachs' ideas on the social construction of the past. ${ }^{53}$ In this respect, however, the most prominent - and often overlooked - reception came from James Joyce, who used Czarnowski's findings to structure his last novel, Finnengans Wake (1939). The critic Riana O'Dwyer counted The Cult among Joyce's most important theoretical inspirations, together with works by Giordano Bruno and Giambattista Vico. ${ }^{54}$ She pointed out that Joyce made use of the most important dimension of Czarnowski's work by adopting the notion of hero as a collective image capable of unifying a community. One of the novel's characters, referred to by a variety of names, is a collective imaginary being whose incarnation is sometimes an invader, sometimes a builder, he is sometimes worshipped and sometimes condemned; most importantly, he has the capacity of languishing in a state of abeyance from which he can be called back to renew society. But the hero's power to do so depends on the society's readiness to call him back. This readiness is realised through ballads, story-telling, funeral rituals, legends of the hero's death and other forms of sustaining his good name. Thus, Joyce linked dreams of the future with recollections of the past, inspired not only by the practices described in Czarnowski's Cult but also by the book's argument on the integrative function of the imagined history.

However, the political subtext of Czarnowski's book was most clearly revealed in the course of its reception in Poland: intellectuals classified The Cult as a study of nation building and looked for its relevance for understanding Polish society's situation. Commenting on the book after Czarnowski's death, the socialist and sociologist Ludwik Krzywicki suggested that a major factor in Czarnowski's choice of research topic was the fact that at the end of the nineteenth century Poles had so eagerly supported Irish aspirations to independence that tsarist censors forbade mentioning the Irish in the Polish-language press. ${ }^{55}$ Although this direct political link is disputable, ${ }^{56}$ the belief that the situation of medieval Ireland described in The Cult mirrored the Polish quest for independence in the nineteenth century was perpetuated in Polish sociology and humanities for good reasons. Not only were the unifying role of Catholicism, the reinventions of the past and the attraction to the images of heroes and saints in both societies considered significant, but the filids were also compared to the Polish patriotic intelligentsia, who longed for the unity of the Polish land. Just as for Hubert, for whom the Celts served as an analogy of republican values, Czarnowski's own national aspirations were reflected by early medieval Ireland. ${ }^{57}$ Czarnowski, at that time an adherent of National Democracy, thanks to this book became a founder of a Polish strand of social constructivism in nation studies and was followed by generations of critical leftist sociologists from Stanisław Ossowski to Jerzy Szacki, who, not unlike Benedict Anderson, Ernst Gellner, Eric Hobsbawm and others, defined nations as communities bounded by invented traditions'. 58

\footnotetext{
53 Barry Schwartz, 'Introduction: the expanding past', Qualitative Sociology, 19, 3 (1996), 275-282.

54 Riana O’Dwyer, 'Czarnowski and Finnegans Wake', 290.

55 Ludwik Krzywicki, 'Foreword', in Stefan Czarnowski, Kultura (Warszawa: Biblioteka Wiedzy i Życia, 1938), VI.

56 Biblioteka Uniwersytetu Warszawskiego (BUW, Dział Rękopisów), Ludwik Krzywicki’s collection, 1447, Paulina Czarnowska to Ludwik Krzywicki, 1937. Thanks to Małgorzata Mazurek for sharing this document.

57 Strenski, 'Henri Hubert', 361-4; Jerzy Szacki. Sto lat socjologii polskiej (Warszawa: Państwowe Wydawnictwo Naukowe, 1995), 95-; Józef Chałasiński, 'Socjologia polska a prądy społeczne i umysłowe’, Myśl Współczesna, 1-2 (1947), 32-3; Jerzy Szacki, 'Koncepcja narodu w socjologii i historii', in Dylematy historiografii idei oraz inne szkica $i$ studia (Warszawa: Państwowe Wydawnictwo Naukowe, 1991), 341-63; Marcin Kula, 'Listy Stanisława Ossowskiego do Niny AssorodobrajKuli', Przegląd Humanistyczny, 1 (2008), 57; Markiewicz-Lagneau, La Formation, 190-6.

58 See, for example, Stanisław Ossowski, Więź społeczna i dziedzictwo krwi (Warszawa: Spółdzielnia Wydawnicza "Książka", 1948); Szacki, 'Koncepcja narodu'.
} 


\section{Towards Comparative World History: Class and Culture at Work}

After the War Czarnowski returned to Durkheimian categories to work on the social construction of space, collaborated with the revived L'Année sociologique and the French Institute of Sociology founded by Marcel Mauss and popularised Celtic literature in Poland. He earned his living by lecturing at the Military School, the Free Polish University (Wolna Wszechnica Polska) and the Warsaw Conservatory, and by publishing in the daily press. For a long time he could not get a professorship at the University of Warsaw to which he aspired. The reasons were numerous, from the underfunding of Polish academia to his own growing radicalisation: 'rumours had been spread: that I was a mason, that I'd sold my soul to the Jews, that to accept me at a state university was to make way to internationalism', he complained writing to Hubert in $1925 .^{59}$ Three years later, in a letter to Mauss, he expressed his general disappointment with Polish politics, including the cult of personality around Marshal Piłsudski: 'all my theses in St. Patrick on the hero legend and cult ... have been confirmed point by point before my very eyes. And yet I'd much rather it had happened somewhere else, or not at all'. ${ }^{60}$

Ironically, Czarnowski's career finally took off in the 1930s when he declared his communist preferences openly. Not only was he granted a chair in the History of Culture at the University of Warsaw (from 1934 onwards, retitled the chair in Sociology and History of Culture), but he was also elected to Poland's two prestigious academies (Polska Akademia Umiejętności and Towarzystwo Naukowe Warszawskie). He subsequently combined his Durkheimian training with new interests in the sociology of work ${ }^{61}$ and in the histories of colonisation and capitalism. ${ }^{62} \mathrm{He}$ lectured on the culture of Polynesia in 1931-2 and on 'Colonization and its Exotic Elements in Western European Culture' in 1932-3. At this point he planned two books: one on general sociology and the other on culture. These were never completed because of his premature death, but he left a first chapter of his book on sociology ${ }^{63}$ and a series of articles in the popular scholarly magazine Knowledge and Life (Wiedza $i \dot{Z} y c i e$ ) between 1932-7, posthumously republished as Culture. ${ }^{64}$ Both projects articulated a methodological basis for a comparative social history and political critique of global capitalism, and they merit reading in the context of the three currents of thought against which Czarnowski developed his theory of culture and defended society as the ultimate object of studies.

First, Czarnowski was troubled by the theories of race and nationalism circulating in Polish academia, for which he blamed German influences. He had complained to Hubert already in the 1920s that 'the forced classifications, hasty generalisations and pervasive nationalism . . . characteristic of German scholars have seriously contaminated a number of Polish archaeologists, who in their majority have been formed by the German school'. ${ }^{65}$ In the 1930 s, to his consternation, race theories were in full swing in various branches of the humanities and social sciences. For instance, in anthropology, taking theses of Nordic superiority at face value, Jan Czekanowski argued that Poland was more Nordic than Germany. Other anthropologists and ethnographers, such as Ludwik Jaxa-Bykowski, Stanisław Poniatowski, Stanisław Żejmo-Żejmis and Karol Stojanowski made similar claims, often against Ukrainians and other minority

\footnotetext{
59 Czarnowski, ‘À Henri Hubert, Varsovie, 3 avril 1925’, in Czarnowski, Listy, 315.

60 Czarnowski, ‘À Marcel Mauss, Varsovie, 11 septembre 1928', in Czarnowski, Listy, 330.

${ }_{61}$ That was the leading topic of his lectures' series in sociology 1933-4 and 1934-5 delivered at the University of Warsaw. See, Czarnowski, Dzieła, Vol. 5, 194-5; Róża Sułek, 'Droga Stefana Czarnowskiego do katedry socjologii w Uniwersytecie Warszawskim', in Antoni Sułek, ed., Socjologia na Uniwersytecie Warszawskim. Fragmenty historii (Warszawa: Wydawnictwo Instytutu Filozofii i Socjologii PAN), 83-93.

62 Czarnowski, Dzieła, Vol. 5, 194-5.

${ }^{63}$ Stefan Czarnowski 'Założenia metodologiczne w badaniu rozwoju społeczeństw ludzkich', in Czarnowski, Dzieła, Vol. 2, 197-221.

64 Czarnowski, Kultura. Thereafter quoted from Czarnowski, Dzieła, Vol. 1.

65 Czarnowski, 'À Henri Hubert, Varsovie, 28 avril 1923', in Czarnowski, Listy, 266-7.
} 
groups. ${ }^{66}$ According to Czarnowski, such approaches were not only politically harmful but also theoretically wrong. Along a Durkheimian line, he kept repeating that it was not race that identified societies but instead their institutions and beliefs.

Secondly, Czarnowski was also in disagreement with diffusionist theories of culture in ethnology, which included the notion of the Kulturkreis applied by the Vienna School of Ethnology and several German scholars. ${ }^{67}$ Although Czarnowski was never ultimately clear on the distinction between society and culture, as a Durkheimian structuralist he claimed the primacy of the former, or even understood culture as a synonym of society. Cultures (in the plural) could develop only within particular societies made of specific fabrics of institutions, social structures and collective representations. ${ }^{68}$

Third, Czarnowski engaged with practices of the historian. As a Durkheimian he understood history as an auxiliary of sociology. Interested in the rise and social consequences of global capitalism, he, however, needed a way to approach this historical process. In accordance with his Durkheimian outlook, he theorised that the history could not be written from the perspective of a single world society or a single culture because such entities did not exist:

Humanity as a social reality has not yet come into being. There are separate groups and relations among these groups; there are cultures, each of which has a different location in space, a different pace and direction of development. These groups and cultures become entangled or mixed or gain control over one another; but each of them is of its own being.

Even now, when the whole globe has been covered by a web of economic relations which constitutes one, albeit still chaotic, system, there is no basis for speaking about the history of contemporary humanity but only about the spread and development of international capitalism and about its functional consequence: a world politics of large concerns and of the powers serving those concerns. ${ }^{69}$

Instead of writing general or global history, therefore, Czarnowski recommended sociologically informed comparison as a method in historical research. He proposed that historians should transform themselves into comparative sociologists of culture, for 'each purely historical inquiry ... will always lead to erroneous conclusions'. ${ }^{70}$ The ultimate goal of researching distinct historical cases was not their description, but the distillation of common (social) mechanisms, aimed at answering questions such as:

How does a culture emerge? Why does it grow, bloom and wither? Under what conditions does contact between cultures result in cultural synthesis or in the decline of one of them? What survives of a declining culture? What are the conditions for the elements of a culture to pervade their non-original environment? How do these elements migrate geographically and endure, potentially even over millennia? ${ }^{71}$

\footnotetext{
${ }^{66}$ On the development of Polish race theories in a wider European context, see Maciej Górny, Wielka Wojna profesorów: nauki o człowieku (1912-1923) (Warszawa: Instytut Historii PAN, 2014); on their political context, see Olga Linkiewicz, 'Applied Modern Science and the Self-Politicization of Racial Anthropology in Interwar Poland', Ab Imperio, 2 (2016), 153-81.

67 Czarnowski was particularly engaged against the ideas of Bernhard Ankermann, Wilhelm Foy, Fritz Gräbner and Wilhelm Schmidt. On diffusionist theories in German-speaking countries, see Martin Rössler, 'Die deutschsprachige Ethnologie bis ca. 1960: Ein historischer Abriss', Kölner Arbeitspapiere zur Ethnologie, 1 (Apr. 2007); Marie-France Chevron, Anpassung und Entwicklung in Evolution und Kulturwandel (Wien: Lit Verlag, 2004); Woodruff D. Smith, Politics and the Sciences of Culture in Germany, 1840-1920 (Oxford: Oxford University Press, 1991), 140-73.

68 Czarnowski, 'Założenia metodologiczne', 204.

69 Czarnowski, 'Założenia metodologiczne', 197.

70 Ibid., 216.

${ }^{71}$ Stefan Czarnowski, 'Kultura', in Czarnowski, Dzieła, Vol. 1, 11.
} 
Czarnowski further proposed an analytical framework with 'work' and 'class' as key categories. A comparison between distinct societies and their cultures was possible, he wrote, owing to their common dependence on 'relations of work'. This was a fusion of the Marxist concept of 'base' and the Durkheimian understanding of work as a socially organised activity. Thus, Czarnowski used Marxist tools to show how social relations (predominantly class and power relations) pervade cultures. ${ }^{72}$ In consequence, class became the ultimate instance of collective representation in Czarnowski's theory by the 1930s, replacing nation, which he had preferred at the beginning of the century.

While Czarnowski was unable to finish his research programme, its guiding questions informed a set of miniature monographs he wrote on, inter alia, ancient Greece, Roman Gaul, heretic social movements in the Middle Ages, the European working class, the Polish peasantry and colonial Central Africa. For instance, using the example of the Romanisation of Celtic Gaul, he highlighted the social mechanisms behind the acquisition of a foreign culture; while peasants kept up the old Celtic rites, he wrote, elites benefited from their participation in Roman rituals. ${ }^{73}$ In another essay he showed how the rites of Polish rural Catholicism mirrored the social relations of the countryside and probed the claim that, although a social group is shaped by the culture propagated by its religion, religion is also influenced by the social characteristic of that group. ${ }^{74}$ In an essay entitled Emergence of a New Culture (Powstanie nowej kultury), he concentrated on working class culture, praising its all-embracing morality, solidarity, harmony, creativity and dynamism. He expressed his hopes that if the world's development is not hindered, if current economic, political and social crises do not thwart factors of production, this culture may become the culture of the nearest future'. ${ }^{75}$

Even though the majority of Czarnowski's cases reflected his expertise in European history, he aimed to show that his method was universal. In an essay on the decay of culture, he dwelt mostly on colonial examples. He distinguished between, on the one hand, peripheral cultural contacts which did not affect local social organisations and, on the other, contacts that resulted in the physical extinction of native populations. However, he was primarily interested in the inbetween cases of social disorganisation caused by modern capitalism supported by Christian missions, which he considered to be the most dangerous form of colonisation. Using varied examples of village leaders turning into local 'greedy potentates or shylocks', of young men unable to start a family because they did not have enough cattle to buy a wife, of girls reduced to prostitution, of recent converts to Christianity getting rid of their 'surplus' wives or of the isolation of the black labour force on the sites of European investment projects (rail transports, roads, ports) precipitating depression and death, Czarnowski advanced his general argument that a culture survived only together with the society from which it emanated. ${ }^{76}$

Czarnowski passed on his research concerns to his students. Two months before his unexpected death, he wrote Marcel Mauss a letter of recommendation for Nina Assorodobraj, who in 1935 had completed her doctoral thesis with him on the Origins of the Polish Working Class. 'She will get in touch with Maurice Halbwachs to continue her studies of the working class ... [but] she would very much like to study work groups organised by Europeans in their colonies. Would you please agree to supervise her?"77 After the Second World War, Assorodobraj, one of the most prominent Polish sociologists of the 1960s, remained faithful to Czarnowski in her interests,

\footnotetext{
72 Jerzy Szacki, 'Socjolog polihistor' in Jan Górski, ed. Wielcy humanistyki polskiej (Wrocław: Zakład Narodowy im. Ossolińskich, 1991), 53-7.

73 Stefan Czarnowski, 'Przejęcie kultury obcej' and 'Przetrwanie kultury', in Czarnowski, Dzieła, Vol. 1, 42-63.

74 Stefan Czarnowski, 'Kultura religijna wiejskiego ludu polskiego', in Czarnowski, Dzieła, Vol. 1, 88-107. French translation: 'La Culture religieuse des paysans polonais', Archives de sciences sociales des religions, 65, 1 (1988), 7-23.

75 Stefan Czarnowski, 'Powstanie nowej kultury', in Czarnowski, Dzieła, Vol. 1, 87.

76 Stefan Czarnowski, 'Opory kultury’, in Czarnowski, Dzieła, Vol. 1, 152-68.

77 Czarnowski, 'À Marcel Mauss, Varsovie, 31 octobre 1937’, in Czarnowski, Listy, 348.
} 
which encompassed industrialisation, class consciousness, collective memory, decolonisation and attempts at comparisons of nation building in Eastern Europe and Western Africa. ${ }^{78}$

The actual impact of Czarnowski's modified Durkheimianism on the research programme of Polish post-war sociology and historiography, however, has remained largely understudied. While it is often noted that only two doctoral theses were completed under Czarnowski's supervision (that of Assorodobraj, and Artur Bardach's on Technological Progress from the Perspective of the Marxist Theory of History), his impact was greater if one considers the many MA students and historians frequenting his seminar. ${ }^{79}$ Undoubtedly, a number of these students did not survive the Holocaust. Still, the key post-war Polish historians, Marian Małowist and Witold Kula, linked their own comparative research programmes to Czarnowski's inspiration. ${ }^{80}$ Małowist's research on the place of East Central Europe in the economy of Europe and on economic relations between Europe, Africa and the Far East, in turn, inspired Immanuel Wallerstein's theory of World-System. Wallerstein singled out Małowist, beside Fernand Braudel, as his most important intellectual stimuli. ${ }^{81}$ (In the first volume of The Modern World System he referred to thirteen works by Małowist on underdevelopment of Eastern Europe, Western colonialism and precolonial Africa. ${ }^{82}$ ) Witold Kula, in the tradition of Czarnowski's entanglements with French social science, maintained a close dialogue with Fernand Braudel and is best known for his Economic Theory of the Feudal System, which presented a model of the Polish economy from the sixteenth to the eighteenth centuries, and - in its broader implications - offered a method for analysing non-capitalist systems. ${ }^{83}$ On the whole, Czarnowski's intellectual legacy may be felt in a new wave of international circulation of knowledge in the 1960s, when again East Central European scholars started to compare their region with the developing world. ${ }^{84}$

\section{Conclusion}

Although Czarnowski's early and late writings differed theoretically and thematically, they were bound together by his belief that history writing should serve sociological purposes. 'For a

78 Nina Assorodobraj-Kula, “'Żywa historia”. Świadomość historyczna: symptomy i propozycje badawcze’, Studia Socjologiczne, 9, 2 (1963), 5-45; Nina Assorodobraj-Kula, 'Rola historii w narodzinach świadomości narodowej w Afryce Zachodniej', Studia Socjologiczne, 24, 1 (1967), 73-109.

79 For details see Sułek, 'Droga Stefana Czarnowskiego', 83-93.

80 Witold Kula, 'Mon “éducation sentimentale”', trans. Thérèse Douchy, Annales. Économies, Sociétés, Civilisations, 44, 1 (1989), 133-46; Marian Małowist, 'Stefan Czarnowski (1879-1937)', in Aleksander Gieysztor, Jerzy Maternicki and Henryk Samsonowicz, eds., Historycy warszawscy ostatnich dwóch stuleci (Warszawa: Czytelnik, 1986), 231-44; on Małowist's biography, see Tomasz Siewierski, Marian Małowist i krąg jego uczniów (Warszawa: Oficyna Wydawnicza Aspra, 2016).

81 Immanuel Wallerstein, The Modern World-System: Capitalist Agriculture and the Origins of the European World-Economy in the Sixteenth Century (New York: Academic Press, 1974), xi; Immanuel Wallerstein, 'Marian Malowist: An Appreciation', in Jean Batou and Henryk Szlajfer, eds., Western Europe, Eastern Europe and World Development, $13^{\text {th }}-18^{\text {th }}$ Centuries: Collection of Essays of Marian Małowist (Leiden: Brill Academic Publishers, 2009). See also Edgar Melton, 'The Agrarian East', in Hamish Scott, ed., The Oxford Handbook of Early Modern European History, 1350-1750, Vol. I (Oxford: Oxford University Press, 2015).

82 See Jacek Czaputowicz and Anna Wojciuk, International Relations in Poland (Basingstoke: Palgrave Macmillan, 2017); Adam F. Kola, 'Marian Małowist World History and its Application to World Literature', in May Hawas, ed., The Routledge Companion to World Literature and World History (New York: Routledge, 2018).

${ }^{83}$ See Jacek Kochanowicz, 'A Periphery at the Centre of Attention: Economic History in Poland', in Francesco Boldizzoni and Pat Hudson, Routledge Handbook of Global Economic History (London: Routledge, 2016).

${ }^{84}$ On the Polish-French circulation of historical knowledge in the post-war context see: Patryk Pleskot, Intelektualni sąsiedzi. Kontakty historyków polskich ze środowiskiem 'Annales' 1945-1989 (Warszawa: IPN, 2010). For a more general picture of socialist globalism and its role in decolonisation, see James Mark and Quinn Slobodian, 'Eastern Europe', in Martin Thomas and Andrew Thompson, eds. The Oxford Handbook of the Ends of Empire, first published on-line Jan 2018. DOI: 10.1093/oxfordhb/9780198713197.013.20. On development economics, see Małgorzata Mazurek, 'Co się stało z Polską Szkołą (Rozwoju?)', interview with Michał Sutowski, Dziennik Opinii, 22 (2016) http://krytykapolityczna.pl/ kultura/historia/mazurek-co-sie-stalo-z-polska-szkola-rozwoju (last visited 2 Feb. 2018). 
historian to fulfil his assignment, he must become a sociologist' he wrote in his most important methodological manifesto. ${ }^{85}$ This meant a Durkheimian quest for both universal categories of analysis that could be applied comparatively to different historical cases and the identification of a genuinely social object of study where other disciplines saw ethnicities, races or material cultures. At the same time, his sociology - despite its changing focus from religions and nations to the rise and consequences of global capitalism - was related to his interests in various aspects of antiquity and early medieval history, most prominently the history of the Celts. He was aware of the social functions of the invented past in the making of modern nations, as he showed in his book on the cult of St. Patrick in Ireland. Historical sources served him, too, as a repository of knowledge for sociological argumentation against race studies and anti-social concepts of culture. In their stead, he called for a sociologically grounded comparative world history ordered around the concepts of class and work.

Czarnowski's unexpected reconfiguration of Durkheimianism into Marxist critique following his return to Poland calls for closer attention to aspects of the Durkheimian School as a movement in international social science. Although the reception of Durkheimianism in various geographical and linguistic areas has been widely studied, it seems that a deeper, more contextualised historicisation is needed to understand both how this school made a global career, and how it was transformed across various localities. The reasons for Durkheimianism's attractiveness outside of France varied. While in some countries, for example Turkey, a transformed Durkheimianism was a way of supporting nationalist interests, ${ }^{86}$ in others, such as Poland, it became a tool of social criticism in the hands of the left. To understand these differences the history of sociology needs to shift away from its traditional focus on the reception of classic works and reflect more on the transnational and national structures of academic worlds, on the mechanisms by which ideas circulate and on the intellectual biographies of cultural brokers. The case of Stefan Czarnowski shows that transnational and transdisciplinary entanglements really do matter for a better understanding of the history of the social sciences. But it also shows that local particularities - in this case, the nation building processes and social tensions of interwar East Central Europe - offered fertile soil for the reformulation and propagation of social scientific ideas.

Cite this article: Wawrzyniak, J. 2019. From Durkheim to Czarnowski: Sociological Universalism and Polish Politics in the Interwar Period. Contemporary European History 28: 172-187. doi: 10.1017/S0960777318000516

85 Czarnowski, 'Założenia metodologiczne', 218.

86 Türkay Salim Nefes, 'Ziya Gökalp's adaptation of Emile Durkheim’s sociology in his formulation of the modern Turkish nation', International Sociology, 28, 3 (2013), 335-50. 